\title{
FLORA DE GRÃO-MOGOL, MINAS GERAIS: APOCYNACEAE s.l. - ASCLEPIADOIDEAE ${ }^{1}$
}

\author{
ALESSANDRO RAPINI*, RENATO DE MELLO-SILVA* \& MARIA LÚCIA KAWASAKI** \\ * Departamento de Botânica, Instituto de Biociências, Universidade de São Paulo, \\ Caixa Postal 11461, 05422-970 - São Paulo, SP, Brasil \\ ** Instituto de Botânica, Caixa Postal 4005, 01061-970 - São Paulo, SP, Brasil
}

Decaisne, J. 1844. Asclepiadaceae. In A.L.P.P. de Candolle (ed.) Prodromus systematis naturalis regni vegetabilis. Fortin, Masson \& Sociorum. Paris, vol. 8, p. 490-665.

Fontella-Pereira, J., Valente, M.C., Harley, R.M. \& Marquete, N.F.S. 1989. Contribuição ao estudo das Asclepiadaceae brasileiras - 24. Checklist preliminar do Estado da Bahia. Rodriguésia 67(41): 81-115.

Fontella-Pereira, J., Valente, M.C. \& Marquete, N.F.S. 1995. Flora da Serra do Cipó, Minas Gerais: Asclepiadaceae. Bol. Bot. Univ. São Paulo 14: 131-179.

Fontella-Pereira, J., Valente, M.C. \& Schwarz, E.A. 1984. Contribuição ao estudo das Asclepiadaceae brasileiras, 21. Asclepiadaceae do município de Ouro Preto, Estado de Minas Gerais - uma sinopse. Bol. Mus. Bot. Kuhlmann 7(2): 63-127.

Fournier, E.P.N. 1885. Asclepiadaceae. In C.F.P. Martius \& A.W. Eichler (eds.) Flora brasiliensis. Lipsiae. Monachii, vol. 6, pars 4, p. 189-332, tab. 50-98.

RapınI, A. 2000. Espinhaço Range, Minas Gerais, Brasil. Asclepiadoideae (Apocynaceae). In R.B. Foster (coord.) Rapid Color Guide 19. Environment \& Conservations/Field Museum. Chicago.

Rapini, A., Mello-Silva, R. \& Kawasaki, M.L. 2001. Asclepiadoideae (Apocynaceae) da Cadeia do Espinhaço de Minas Gerais, Brasil. Bol. Bot. Univ. São Paulo 19: 55-169.

1. Lâmina foliar indumentada. Cálice abaxialmente pubescente, hirsuto ou piloso.

2. Sépalas com mais de $4 \mathrm{~mm}$ compr. Corola com mais de $1 \mathrm{~cm}$ compr. Ápice do ginostégio rostrado em um apêndice bífido, excluso Oxypetalum

3. Erva. Folhas subsésseis Lobos da corona escamiformes, corniculados adaxialmente. Retináculo laminar, ca. $1 \mathrm{~mm}$ compr.; polínios reniformes, ca. 0,65 $\mathrm{mm}$ compr. O. erectum

3'. Trepadeira ou arbusto volúvel. Pecíolo com mais de $4 \mathrm{~mm}$ compr. Lobos da corona bilobulados, cristados adaxialmente. Retináculo conduplicado, mais de 1,7 mm compr.; polínios subsigmóides, mais de $1,6 \mathrm{~mm}$ compr. O. strictum

2'. Sépalas até $2 \mathrm{~mm}$ compr. Corola com menos de $5 \mathrm{~mm}$ compr. Ápice do ginostégio mamilado, incluso Ditassa

4. Trepadeira. Lâmina foliar aguda a mucronada no ápice.

5. Ramos híspidos a pilosos. Lâmina foliar aguda no ápice. Pedicelo 5-7 mm compr. Corola amarelada, abaxialmente glabra, mais de $4 \mathrm{~mm}$ compr. Retináculo com mais de 0,2 mm compr. D. hispida

5'. Ramos velutino-tomentosos. Lâmina foliar mucronada no ápice. Pedicelo 2-5 mm compr. Corola geralmente creme, abaxialmente hirsuta, menos de $3 \mathrm{~mm}$ compr. Retináculo com menos de $0,2 \mathrm{~mm}$ compr.

D. pohliana

4'. Erva a arbusto. Lâmina foliar arredondada no ápice.

6. Folhas opostas ou 3(4)-vertiladas; lâmina oblonga, cuneada, obtusa ou arredondada na base. Pedicelo com mais de 1,5 mm compr. Segmentos internos da corona triangulares, quase da altura do ginostégio. Folículo ca. $2,5 \mathrm{~mm}$ compr.

' Trabalho realizado conforme o planejamento apresentado por Pirani el al. (2003). Bol. Bot. Univ. São Paulo 21(1): 1-24. 
6'. Folhas opostas; lâmina cordiforme, cordada ou quase na base. Pedicelo com menos de $1 \mathrm{~mm}$ compr. Segmentos internos da corona inconspícuos ou lineares e mais altos que o ginostégio. Folículos com mais de $3,5 \mathrm{~mm}$ compr.

7. Lâmina foliar patente ou quase, pilosa em ambas as faces. Sépalas 1,1-1,4 mm compr. Corola amarela, adaxialmente glabra no centro das lacínias; lacínias com menos de $2 \mathrm{~mm}$ compr. Segmentos internos da corona lineares, mais altos que o ginostégio. Caudículos articulados D. decussata

7'. Lâmina foliar geralmente ereta, adaxialmente hirsuta, abaxialmente alvo-tomentosa a vilosa. Sépalas 1,4-2,2 $\mathrm{mm}$ compr. Corola alva ou creme, adaxialmente barbada a barbelada na porção mediana; lacínias com mais de $2 \mathrm{~mm}$ compr. Segmentos internos da corona inconspícuos. Caudículos retos

l'. Lâmina foliar glabra ou com tricomas esparsos na base, nas nervuras e/ou na margem. Cálice glabro ou com tricomas esparsos, geralmente na base ou na margem das sépalas.

8. Erva. Folhas sésseis ou quase, cordiformes a deltóides ou triangulares a estreitamente lanceoladas. Barjonia

9. Folhas cordiformes a deltóides, ca. $2 \mathrm{~cm}$ compr., cordadas na base. Cimeiras até 4-floras em tirsóide frondoso; pedicelo com mais de $5 \mathrm{~mm}$ compr. Lobos da corona duplos B. chloraeifolia

9'. Folhas triangulares a estreitamente lanceoladas, mais de $4 \mathrm{~cm}$ compr., subcordadas a truncadas na base. Cimeiras 2-floras em tirsóide áfilo; pedicelo ca. $3 \mathrm{~mm}$ compr. Lobos da corona simples B. erecta

8'. Trepadeira. Folhas pecioladas; lâmina linear a oblonga, elíptica, oval ou oboval.

10. Corola com mais de $8 \mathrm{~mm}$ compr.

11. Ramos unilateralmente pubescentes. Corola urceolada, amarelo-esverdeada. Lobos da corona sagitados, carnosos na base, internamente subulados, unidos ao dorso das anteras. Polínios eretos. Ápice do ginostégio cônico Marsdenia suberosa

11'. Ramos glabros. Corola rotácea, esverdeada, eventualmente acastanhada na base e/ou adaxialmente. Lobos da corona cotiliformes, unidos ao ginostégio e à corola. Polínios pendentes ou inseridos lateralmente aos caudículos. Ápice do ginostégio achatado a quase plano

12. Lâmina foliar sagitada na base. Cimeiras 2-floras. Corola com mais de $2 \mathrm{~cm}$ compr. Lobos das corona mais altos que o ginostégio. Caudículos inseridos na porção apical do retináculo. Polínios subdeltóides, ca. 0,85 mm compr.

12'. Lâmina foliar cuneada a levemente cordada na base. Cimeiras corimbosas, até 6 floras. Corola com menos de $1 \mathrm{~cm}$ compr. Lobos da corona da altura do ginostégio. Caudículos inseridos na porção basal do retináculo. Polínios obovóides a subglobosos, ca. $0,45 \mathrm{~mm}$ compr.

10 . Corola até $4,5 \mathrm{~mm}$ compr.

13. Lâmina foliar linear, até $3 \mathrm{~mm}$ larg.

14. Lâmina foliar com mais de $2,8 \mathrm{~cm}$ compr. Corola urceolada, adaxialmente barbada no ápice, serícea no terço médio, glabra na base; tubo ca. $3 \mathrm{~mm}$ compr., 3 vezes maior que as lacínias. Corona ausente Hemipogon carassensis

14'. Lâmina foliar até $2,8 \mathrm{~cm}$ compr. Corola rotácea a subcampanulada, adaxialmente papilosa ou puberulenta, barbelada ou não na base; tubo até $1 \mathrm{~mm}$ compr., menor que as lacínias. Corona presente Ditassa

15. Corola adaxialmente puberulenta; tubo até $0,6 \mathrm{~mm}$ compr., mais de 4 vezes menor que as lacínias. Segmentos externos da corona subretangulares a subovais. Caudículos retos D. capillaris

15'. Corola adaxialmente papilosa ou puberulenta, barbelada na base; tubo com mais de $0,6 \mathrm{~mm}$ compr., menos de 3 vezes menor que as lacínias. Segmentos externos da corona rômbicos. Caudículos geniculados

D. cordeiroana

13'. Lâmina foliar oval, oboval, elíptica ou oblonga, mais de $3 \mathrm{~mm}$ larg.

16. Ramos glabros. Cimeiras axilares, opostas. Corola adaxialmente barbelada ou setulosa na base 
floras; pedúnculo com mais de $4 \mathrm{~mm}$ compr. Sépalas ca. $1 \mathrm{~mm}$ compr. Corola creme ou esverdeada, mais de $3 \mathrm{~mm}$ compr. Segmentos internos da corona subquadrangulares, seliformes, mais baixos que o ginostégio. Polínios oblongos a obovóides, ca. $0,45 \mathrm{~mm}$ compr.

M. adnata

17'. Pecíolo ca. $2 \mathrm{~mm}$ compr.; lâmina foliar geralmente com tricomas na margem e na nervura central da face adaxial. Cimeiras 4-10-floras; pedúnculo até 4 $\mathrm{mm}$ compr. Sépalas ca. 0,65 mm compr. Corola vinácea, ca. 1,85 mm compr. Segmentos internos da corona lineares, mais altos que o ginostégio. Polínios estreitamente ovais ou dacrióides, ca. 0,15 mm compr.

M. melantha

16'. Ramos pubescentes. Cimeiras subaxilares, alternas. Corola adaxialmente uniformemente indumentada a quase glabra.

18. Pecíolo com mais de $2 \mathrm{~cm}$ compr.; lâmina oval, mais de $4 \mathrm{~cm}$ compr., mais de $1,5 \mathrm{~cm}$ larg., reniforme a auriculada na base. Corola adaxialmente com raros tricomas; tubo ca. 1,5 mm compr., maior que as lacínias. Lobos da corona simples, alternos às anteras Cynanchum roulinioides

18'. Pecíolo até $5 \mathrm{~mm}$ compr.; lâmina geralmente oboval, elíptica ou oblonga, até 2,4 $\mathrm{cm}$ compr., até $1,4 \mathrm{~cm}$ larg., cuneada a arredondada na base. Corola adaxialmente papilosa ou puberulenta; tubo com menos de $1 \mathrm{~mm}$ compr., menor que as lacínias. Lobos da corona duplos, opostos às anteras Ditassa 19. Sépalas ca. $2,5 \mathrm{~mm}$ compr. Corola adaxialmente papilosa. Segmentos externos da corona mais baixos que o ginostégio D. glazioui

19'. Sépalas até $2 \mathrm{~mm}$ compr. Corola adaxialmente puberulenta. Segmentos externos da corona mais altos que o ginostégio.

20. Lâmina foliar elíptica. Segmentos externos da corona triangulares ....... D. obcordata 20'. Lâmina foliar oboval ou oblonga. Segmentos externos da corona subulados ou caudados.

21. Lâmina foliar 1,7-2,4 cm compr. Sépalas ca. $1 \mathrm{~mm}$ compr. Corola ca. $3 \mathrm{~mm}$ compr. Segmentos externos da corona subulados; os internos oblongos, quase da altura do ginostégio D. retusa

21'. Lâmina foliar 0,7-1,7 cm compr. Sépalas ca. $2 \mathrm{~mm}$ compr. Corola ca. 4,5 mm compr. Segmentos externos da corona subobovais, caudados; os internos subulados, mais altos que o ginostégio

D. succedanea

\section{Barjonia Decne.}

Ervas ou subarbustos; ramos glabros. Folhas opostas, sésseis ou quase, lanceoladas a deltóides, geralmente cordadas na base, espessadas na margem, agudas a mucronadas no ápice, glabras. Cimeiras subaxilares, alternas. Cálice glabro, adaxialmente com até 1 par de coléteres entre as sépalas. Corola rotácea a campanulada. Corona unida externamente à corola e internamente ao ginostégio; lobos simples ou duplos, livres entre si, opostos às anteras. Polínios pendentes ou inseridos lateralmente aos caudículos. Ápice do ginostégio mamilado a umbonado, incluso. Folículos lanceolóides, glabros.

1.1. Barjonia chloraeifolia Decne. in A.DC., Prodr. 8: 512. 1844 (como "chloraefolia").

Erva ca. $80 \mathrm{~cm}$ alt. Folhas cordiformes a deltóides, ca. $2 \mathrm{~cm}$ compr., ca. $3 \mathrm{~cm}$ larg., as apicais progressivamente menores, cordadas na base, semi-amplexicaules. Cimeiras umbeliformes até 4-floras em tirsóide frondoso; pedúnculo até $4 \mathrm{~mm}$ compr.; pedicelo $0,6-1 \mathrm{~cm}$ compr. Sépalas ovais a triangulares, ca. $1 \mathrm{~mm}$ compr. Corola subcampanulada, esverdeada, abaxialmente glabra, adaxialmente esparsamente papilosa na porção apical, papilosa a puberulenta no terço médio, barbada na base das lacínias; tubo ca. $1 \mathrm{~mm}$ compr.; lacínias ca. $4 \mathrm{~mm}$ compr. Lobos da corona duplos; segmentos externos triangulares, subulados, revolutos, geralmente superando o ginostégio em altura; os internos suboblongos, mais baixos que o ginostégio. Retináculo elipsóide ou quase, ca. 0,3 mm compr.; caudículos retos ca. 0,05 mm compr.; polínios elipsóides, ca. 0,55 mm compr. Folículos 4,2-5,5 cm compr. (Fig. 1. A-D)

Campos et al. CFCR 13357 (SPF). 
Campos rupestres da Cadeia do Espinhaço, em Minas Gerais e na Bahia. Floresce entre dezembro e junho; em Grão-Mogol, foi coletada com flores e frutos em setembro.

1.2. Barjonia erecta (Vell.) K.Schum. in Engl. \& Prantl, Nat. Pflanzenfam. 4(2): 285. 1895.

Erva ca. $1 \mathrm{~m}$ alt. Folhas triangulares a estreitamente lanceoladas, 5-7 cm compr., 0,5-2,6 cm larg., subcordadas a truncadas na base. Cimeiras 2-floras em tirsóides áfilos; pedúnculo ca. $2 \mathrm{~mm}$ compr.; pedicelo ca. $3 \mathrm{~mm}$ compr. Sépalas largamente ovais, ca. 1,7 mm compr. Gorola subcampanulada, creme-vinácea, abaxialmente glabra, adaxialmente papilosa na metade superior, bar- bada na metade basal das lacínias; tubo ca. 1,2 $\mathrm{mm}$ compr.; lacínias ca. 3,8 mm compr. Lobos da corona simples; segmentos ovais a triangulares, subulados, revolutos, mais altos que o ginostégio. Retináculo obovóide, ca. 0,4 $\mathrm{mm}$ compr.; caudículos retos, ca. 0,1 $\mathrm{mm}$ compr.; polínios subelipsóides, ca. 0,45 mm compr. (Fig. 1. E-H)

\section{Rapini E Kawasaki 733 (SPF).}

Geralmente em cerrados e campos rupestres, no Paraná, São Paulo, Minas Gerais, Mato Grosso do Sul, Goiás e Distrito Federal, sendo mencionada também para o Suriname. Floresce ao longo do ano, principalmente em abril. Em Grão-Mogol, foi coletada com flores em março.

\section{Blepharodon Decne.}

Trepadeiras, mais raramente ervas; ramos glabros. Folhas opostas, pecioladas, raramente sésseis, elípticas a lineares. Cimeiras subaxilares, alternas. Cálice adaxialmente com 1-4 coléteres, freqüentemente fundidos, entre as sépalas. Corola rotácea a subglobosa. Corona unida ao ginostégio e à corola; lobos geralmente cotiliformes, opostos às anteras, livres entre si. Polínios pendentes ou inseridos lateralmente aos caudículos. Ápice do ginostégio achatado a quase plano, incluso. Folículos geralmente cilíndricos, acuminados ou dacrióides.

\subsection{Blepharodon ampliflorum E.Fourn. in Mart. \& Eichler,} Fl. bras. 6(4): 304. 1885 .

Trepadeira. Pecíolo ca. 9 mm compr.; lâmina linear a elíptica, 5,7-10 cm compr., 0,5-2,1 cm larg., sagitada na base; plana na margem, aguda no ápice, glabra ou com tricomas esparsos na margem. Cimeiras 2-floras; pedúnculo 3-4,5 cm compr.; pedicelo ca. $1,5 \mathrm{~cm}$ compr. Cálice glabro; sépalas ovais a lanceoladas, ca. $4,5 \mathrm{~cm}$ compr. Corola rotácea, abaxialmente verde-clara, glabra, adaxialmente acastanhada, ciliada perto da margem; tubo ca. $6 \mathrm{~mm}$ compr.; lacínias ca. 1,6 cm compr. Lobos da corona com uma porção proximal conduplicada longitudinalmente, mais alta que o.ginostégio e unida a uma porção distal oblonga. Retináculo subelipsóide, ca. 0,74 mm compr.; caudículos levemente arqueados, ascendentes, inseridos na porção apical do retináculo, ca. 0,34 mm compr.; polínios subdeltóides, ca. $0,85 \mathrm{~mm}$ compr. (Fig. 1. I-L)

\section{Silva et al. CFCR 12657 (SPF).}

Bordas de mata, vegetações abertas ou perturbadas, no Paraná, São Paulo, Minas Gerais e Bahia, sendo mencionada para o Rio Grande do Sul e Pernambuco. Floresce entre outubro e abril; em Grão-Mogol, foi coletada com flores em dezembro.

2.2. Blepharodon nitidum (Vell.) J.F.Macbr., Publ. Field
Mus. Nat. Hist., Bot. Ser. 11(1): 34. 1931.

Trepadeira. Pecíolo 0,7-1,5 cm compr.; lâmina oval a elíptica, 3,9-7,4 cm compr., 1,2-3,5 cm larg., cuneada a levemente cordada na base, levemente revoluta na margem, acuminada a cuspidada no ápice, glabra ou com tricomas esparsos na margem. Cimeiras corimbosas, até 6-floras; pedúnculo até $2 \mathrm{~mm}$ compr.; pedicelo 1,2-1,8 cm compr. Cálice glabro; sépalas ovais, ca. $3 \mathrm{~mm}$ compr. Corola rotácea, esverdeada, freqüentemente acastanhada na base, abaxialmente glabra, adaxialmente pilosa a vilosa próximo à margem; tubo ca. $2 \mathrm{~mm}$ compr.; lacínias ca. $7 \mathrm{~mm}$ compr. Lobos da corona cotiliformes com uma porção proximal conduplicada longitudinalmente, da altura do ginostégio, unida a uma porção distal oval a lanceolada. Retináculo ligulado a trulóide, ca. 0,5 mm compr.; caudículos arqueados, inseridos na porção basal do retináculo, ca. $0,17 \mathrm{~mm}$ compr.; polínios obovóides a subglobosos, ca. 0,45 mm compr. Folículos 6,3-8,7 cm compr., esparsamente pubescentes. (Fig. 1. M-O)

Barreto Eo Brade 3355 (RB); Pirani et al. CFCR 13307 (SPF); Sano et al. 917(CTES, SPF); Zappi et al. CFCR 12089 (NY, RB, SPF).

Campos, cerrados, restingas, matas e brejos de praticamente todo Brasil, chegando até o Paraguai e países do norte da América do Sul. Floresce ao longo do ano. 


\section{Cynanchum $\mathrm{L}$.}

Trepadeiras, ervas ou subarbustos. Folhas opostas, raramente verticiladas, geralmente pecioladas, ovais ou oblongas, cordadas a reniformes na base. Cimeiras subaxilares ou axilares, alternas. Cálice adaxialmente com até 3 coléteres entre as sépalas. Corola rotácea a urceolada. Corona unida à corola e ao ginostégio; lobos simples, opostos ou raramente alternos às anteras, livres entre si ou unidos na base. Polínios pendentes. Ápice do ginostégio geralmente mamilado a depresso, incluso. Folículos fusiformes.

3.1. Cynanchum roulinioides (E.Fourn.) Rapini, comb. ined.

Trepadeira; ramos unilateralmente pubescentes, glabrescentes para a base. Pecíolo 2,3-3,3 cm compr.; lâmina oval, 4,5-7,5 cm compr., 1,9-3,4 cm larg., reniforme a auriculada na base, plana na margem, acuminada no ápice, tricomas esparsos nas nervuras adaxiais e na margem. Cimeiras racemiformes, subaxilares, até 11floras; pedúnculo 1,4-6 mm compr.; pedicelo ca. $2 \mathrm{~mm}$ compr. Cálice com tricomas esparsos na margem da base; sépalas oblongas, ca. 1,5 mm compr. Corola campanulada, creme-vinácea, abaxialmente glabra, adaxialmente com raros tricomas; tubo ca. 1,5 mm compr.; lacínias ca. $1 \mathrm{~mm}$ compr. Lobos da corona oblongos, involutos, alternos às anteras, da altura do ginostégio. Retináculo estreitamente ovóide a elipsóide, ca. 0,13 $\mathrm{mm}$ compr.; caudículos geniculados, ca. $0,15 \mathrm{~mm}$ compr.; polínios oblongos, ca. 0,3 mm compr. Ápice do ginostégio apiculado. Folículo ca. $4 \mathrm{~cm}$ compr., glabro. (Fig. 1. P-R)

Furlan et al. CFCR 699 (SPF); Rapini E Kawasaki 740 (SPF).

Piauí, Ceará e serras do Planalto Central brasileiro, chegando até o Paraguai. Floresce principalmente de janeiro a abril.

\section{Ditassa R.Br.}

Subarbustos, ervas ou trepadeiras. Folhas opostas, raramente verticiladas, pecioladas a sésseis, lineares a ovais. Cimeiras subaxilares, alternas. Cálice adaxialmente apresentando até 3 coléteres entre as sépalas. Corola rotácea a campanulada. Corona unida à corola e ao ginostégio, raramente ausente; lobos geralmente duplos, livres ou unidos entre si na base, opostos às anteras, segmentos internos freqüentemente incospícuos. Polínios pendentes. Ápice do ginostégio geralmente mamilado, incluso. Folículos fusiformes ou cilíndricos.

\subsection{Ditassa acerosa Mart., Nov. Gen. sp. pl. 1: 53. 1824.}

Subarbusto ereto, freqüentemente volúvel no ápice; ramos hirsutos. Folhas opostas ou 3(4)-verticiladas; pecíolo até $1 \mathrm{~mm}$ compr.; lâmina oblonga, $4-9 \mathrm{~mm}$ compr., 0,7-1 mm larg., cuneada, obtusa ou arredondada na base, revoluta na margem, arredondada no ápice, adaxialmente hirtela a hispidulosa, abaxialmente hirsuta. Cimeiras umbeliformes a racemiformes, até 9-floras; pedúnculo até $5 \mathrm{~mm}$ compr.; pedicelo $1,5-4(-5) \mathrm{mm}$ compr. Cálice abaxialmente hirsuto; sépalas ovais a lanceoladas, ca. $1 \mathrm{~mm}$ compr. Corola subcampanulada, amarelo-esverdeada, abaxialmente hirsuta, adaxialmente papilosa, glabra na base; tubo $0,35-0,8 \mathrm{~mm}$ compr.; lacínias ca. 1,5 mm compr. Segmentos da corona triangulares; os externos pouco mais altos que ginostégio; os internos quase da altura do ginostégio. Retináculo estreitamente oblongo a cilíndrico, ca. 0,13 mm compr.; caudículos geniculados, ca $0,1 \mathrm{~mm}$ compr.; polínios dacrióides, ca. $0,13 \mathrm{~mm}$ compr. Folículo ca. 2,5 cm compr., hirsuto. (Fig. 2. A-C)
Furlan et al. CFCR 689 (CTES, INPA, RB, SPF, US); Hatschbach et al. 54174 (MBM); Lima 951 (RB); Magalhães 18397 (HB, UB); Martinelli 5786 (RB), 5798 (RB); Rossi et al. CFCR 1008 (CEPEC, RB, SPF, UB, UEC).

Campos e cerrados, mais raramente em restingas, no Paraná, São Paulo, Espirito Santo, Minas Gerais, Bahia e Mato Grosso do Sul, no Brasil, chegando até a Argentina. Floresce ao longo do ano, principalmente no primeiro semestre.

4.2. Ditassa capillaris E.Fourn. in Mart. \& Eichler, Fl. bras. 6(4): 253. 1885.

Trepadeira; ramos unilateralmente pubescentes. Pecíolo 2-4 mm compr.; lâmina linear, 0,6-1,5 cm compr., 0,3-1,5 mm larg., cuneada a arredondada na base, revoluta na margem, aguda a acuminada no ápice, glabra ou com tricomas esparsos na base e na nervura adaxial. Cimeiras umbeliformes, 1-2(3)-floras; pedúnculo 0,3-1 cm compr.; pedicelo 0,5-1 cm compr. Cálice 


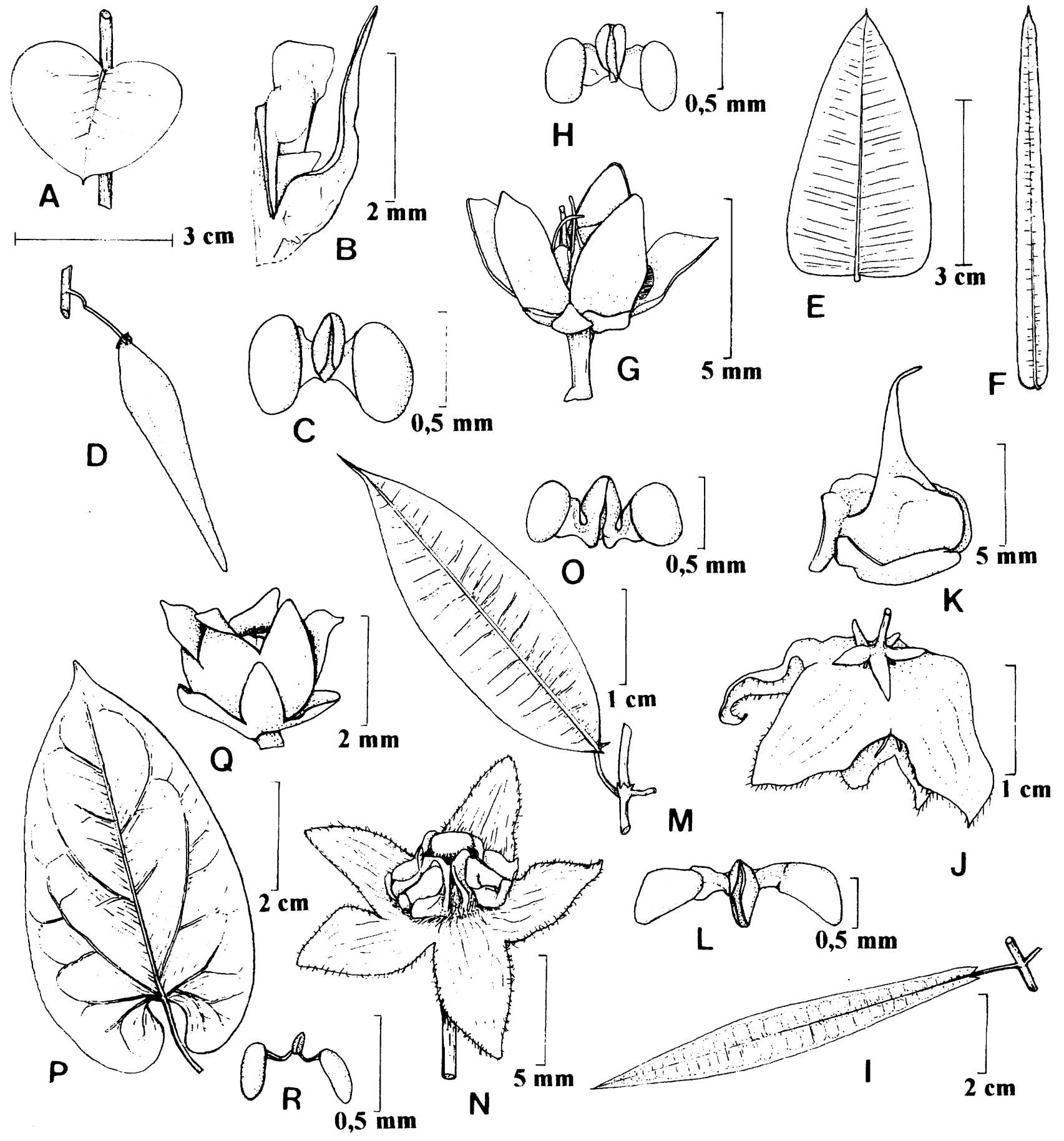

Fig. 1. APOCYNACEAE (ASCLEPIADOIDEAE). A-D. Barjonia chloraeifolia: A. Follha; B. Estame com lobo da corona, vista lateral; C. Polinário; D. Folículo. E-H. B. erecta: E-F. Folha; G. Flor; H. Polinário. I-L. Blepharodon ampliflorum: I. Folha; J. Flor; K. Antera com lobo da corona em vista lateral; L. Polinário. M-O. B. nitidum: M. Folha; N. Flor; O. Polinário. P-R. Cynanchum roulinioides: P. Folha; Q. Flor; R. Polinário. (A-D. CFCR 13357; E-F. Rapini 733; I-L. CFC:R 12657; M-O. CFCR 13307) P. Rapini 741), Q-R. (TCCR 699). 
glabro; sépalas ovais, 1,2-1,5 $\mathrm{mm}$ compr. Corola rotácea, creme ou alva, abaxialmente glabra, adaxialmente puberulenta; tubo 0,3-0,6 mm compr.; lacínias 2,5-3 mm compr. Segmentos da corona quase da altura do ginostégio; os externos sub-retangulares a subovais; os internos lanceolados, levemente revolutos. Retináculo elipsóide a ligulado, 0,2-0,23 mm compr.; caudículos retos, 0,05-0,1 mm compr.; polínios elipsóides, ca. 0,2 mm compr. (Figs. 2. D-F)

Pirani et al. CFCR 13169 (K, MO, RB, SPF), CFCR 11471 (RB, SPF); Rapini et al 857 (SPF).

São Paulo, Minas Gerais, Bahia, Piauí e Ceará, geralmente em caatinga, cerrado e capão. Floresce principalmente entre novembro e julho.

4.3. Ditassa cordeiroana Fontella, Bradea 6(27): 238. 1993.

Trepadeira; ramos unilateralmente pubescentes, raramente glabros, suberificados para a base. Pecíolo 1-3 mm compr.; lâmina linear, 0,8-2,8 cm compr., 0,5-1,2 $\mathrm{mm}$ larg., cuneada na base, revoluta na margem; aguda a acuminada no ápice, glabra. Cimeiras umbeliformes, 1-3(4)-floras; pedúnculo 1-5 mm compr.; pedicelo 2-4 $\mathrm{mm}$ compr. Cálice glabro; sépalas ovais a lanceoladas, 0,8-0,95 $\mathrm{mm}$ compr. Corola subcampanulada, alva, amarelada, creme ou esverdeada, abaxialmente glabra, adaxialmente papilosa ou puberulenta, barbelada na base; tubo 0,7-1 mm compr; lacínias 1,5-2 mm compr. Segmentos externos da corona rômbicos, mais altos que o ginostégio; os internos suboblongos, pouco mais baixos que os externos. Retináculo estreitamente elipsóide a oblongo, 0,14-0,18 mm compr.; caudículos geniculados, ca. 0,08 mm compr.; polínios subglobosos a piriformes, 0,11-0,14 mm compr. Folículos 2,5-4,3 cm compr., glabros. (Fig. 2. G-I)

Cordeiro et al. CFCR 8978 (RB, SPF); Cordeiro ث MelloSilva CFCR 10017 (RB, SPF), CFCR 11457(holótipo SPF, isótipos K, MO, RB); Ferreira et al. 707, 740 (RB); Fiaschi et al. 166 (R, SPF); Giulietti et al. CFCR 9854 (CEPEC, G, NY, RB, SPF); Hatschbach 41325 (MBM); Hatschbach 8 Ribas 52021, 54943 (MBM); Irwin et al. 23515 (F); Kawasaki et al. CFCR $8370(\mathrm{RB}, \mathrm{SPF}, \mathrm{W})$; Magalhães $18352(\mathrm{HB})$; Martinelli 5826 (RB); Mello-Silva et al. CFCR 11457 (RB, SPF); Rapini et al. 854 (SPF); Zappi et al. CFCR 12052 (F, $\mathrm{HB}, \mathrm{RB}, \mathrm{SPF})$.

Restrita à região de Grão-Mogol, em campos, cerrados abertos e carrascos, geralmente em solos arenosos, sobre arbustos ou entre pedras. Floresce ao longo do ano.
4.4. Ditassa decussata Mart., Nov. Gen. sp. pl. 1: 51.1824.

Arbusto ereto, ca. $60 \mathrm{~cm}$ alt.; ramos vilosos. Folhas subsésseis; lâmina cordiforme, revolutamente cimbiforme, patentes ou quase, $0,8-1,3 \mathrm{~cm}$ compr., $0,6-1,4 \mathrm{~cm}$ larg., as apicais progressivamente menores, subcordada na base, revoluta na margem, arredondada no ápice, pilosa em ambas as faces. Cimeiras umbeliformes ou quase, até 3-floras; pedúnculo ca. 0,9 $\mathrm{mm}$ compr.; pedicelo ca. 0,9 $\mathrm{mm}$ compr. Cálice abaxialmente piloso; sépalas ovais, 1,1-1,4 mm compr. Corola subcampanulada, amarela, abaxialmente pilosa, adaxialmente papiloso a puberulenta na porção apical e paralelamente à margem, glabra no centro das lacínias; tubo 0,5-0,7 mm compr.; lacínias 1,6-1,7 mm compr. Segmentos da corona lineares; os externos mais altos que o ginostégio; os internos mais altos que os externos. Retináculo cônico a suboblongo, ca. $0,1 \mathrm{~mm}$ compr.; caudículos articulados, ca. $0,1 \mathrm{~mm}$ compr.; polínios ovóides a reniforme, ca. 0,2 $\mathrm{mm}$ compr. Folículo ca. $4,2 \mathrm{~cm}$ compr., viloso. (Fig. 2. J-N)

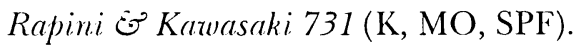

Entre rochas, nos campos rupestres da Cadeia do Espinhaço de Minas Gerais, sendo mencionada também para a restinga, no Espirito Santo. Floresce ao longo do ano, principalmente no primeiro semestre; em Grão-Magol, foi coletada com flores em março.

4.5. Ditassa ditassoides (Silveira) Fontella, Loefgrenia 43: 1. 1970 .

Erva a subarbusto ereto, $20-50 \mathrm{~cm}$ alt.; ramos hirsuto-tomentosos. Pecíolo até $1 \mathrm{~mm}$ compr.; lâmina estreitamente cordiforme, geralmente ereta, $0,8-1,9 \mathrm{~cm}$ compr., 3-9 mm larg., as apicais progressivamente menores, cordada na base, revoluta na margem, arredondada no ápice, adaxialmente hirsuta, abaxialmente alvo-tomentosa a vilosa. Cimeiras glomerulosas, até 6floras. Cálice abaxialmente hirsuto; sépalas lanceoladas, 1,4-2,2 mm compr. Corola subcampanulada, alva ou creme, abaxialmente hirsuta, adaxialmente papilosa na porção apical, barbada a barbelada na mediana, glabra na basal; tubo 0,5-1 mm compr.; lacínias 2,2-2,5 $\mathrm{mm}$ compr. Segmentos externos da corona triangulares, pouco mais altos ou da altura do ginostégio; os internos inconspícuos. Retináculo oblongo a elipsóide, 0,15-0,16 mm compr.; caudículos retos, 0,05-0,08 $\mathrm{mm}$ compr.; polínios ovóides a oblongo, 0,2-0,23 mm compr. Folículos $4-5,5 \mathrm{~cm}$ compr., pubescentes a hirtelos. (Fig. 2. O-R)

Cordeiro et al. CFCR 953 (RB, SPF); Fïaschi et al. 171 


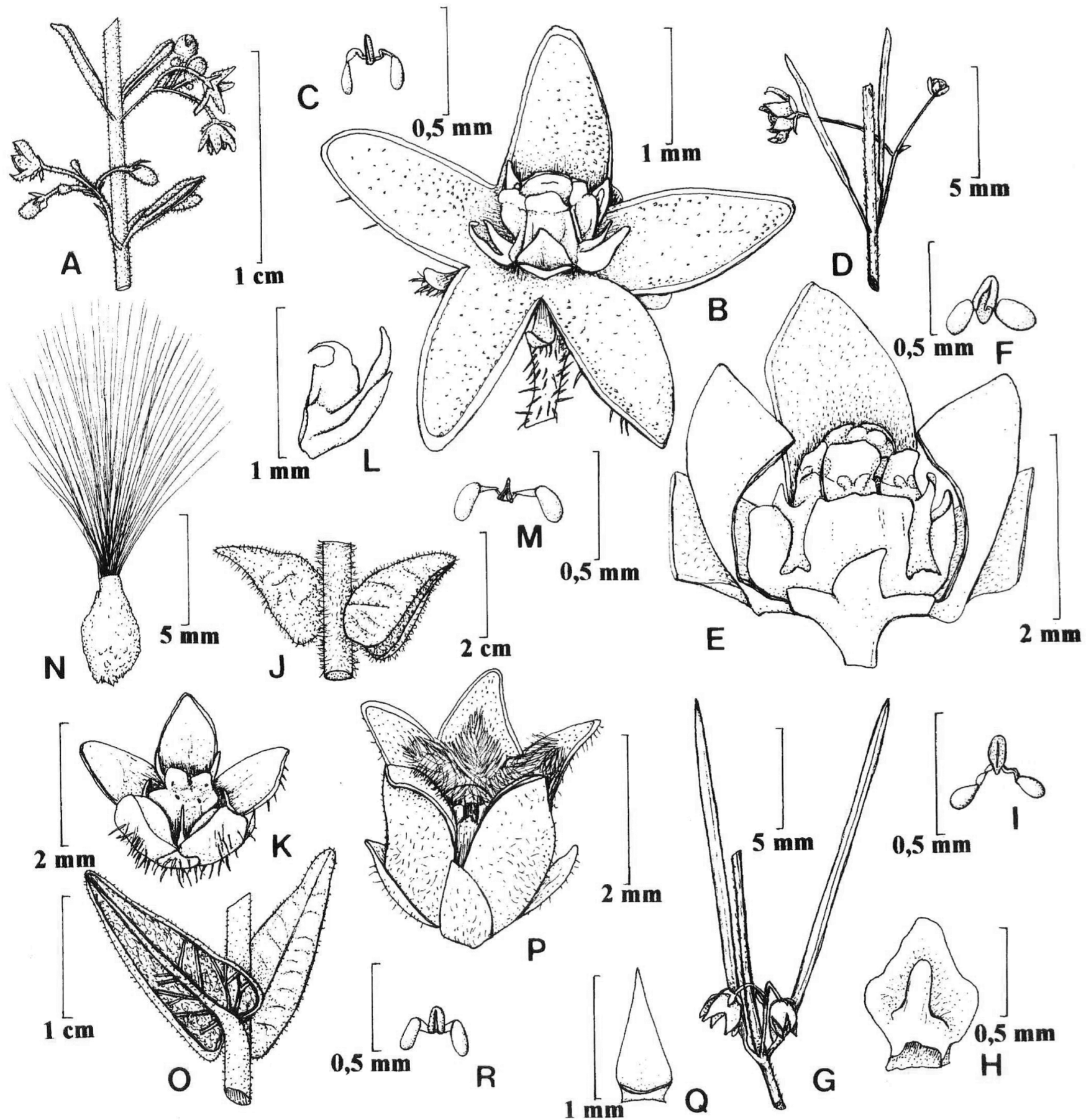

Fig. 2. APOCYNACEAE (ASCLEPIADOIDEAE). Dilassa. A-C. D. acerosa: A. Parte do ramo com flores; B. Flor; C. Polinário. D-F. D. capillaris; D. Par de folhas com inflorescência; E. Flor com lacínias recortadas, mostrando a corona; F. Polinário. G-I. D. corleiroana: G. Par de folhas com inflorescência; H. Lobo da corona, vista adaxial; I. Polinário. J-N. D. decussata: J. Par de folhas; K. Flor; L. Estame com lobo da corona, vista lateral; M. Polinário; N. Semente. O-R. D. dilassoides: O. Par de folhas; P. Flor; Q. Lobo da corona, vista adaxial; R. Polinário. (A-C. CFCR 1008; D. CFCR 10017; E-F. CFCR 13169; G-I. CFCR 121052; J-N. Rapini 731; O-R. CFCR 13082). 
(SPF); Freire-Fierro et al. CFCR 12467 (RB, SPF); Grandi et al. s.n. (BHCB 13613, BHCB 13629); Irvin et al. 23661 (HB, UB); Menezes et al. CFCR 9641 (G, RB, SPF, UEC); Rapini et al. 343 (F, MBM, SP, W), 855 (SPF); Simonis है Cordeiro CFCR 4081 (RB, SPF); Zappi et al. CFCR 13082 (RB, SPF, W).

Campos rupestres de Minas Gerais, Goiás e Tocantins. Em Grão-Mogol, foi coletada em altitudes entre 850-1200 m, geralmente em solo arenoso ou pedregoso. Floresce ao longo do ano, mais intensamente em fevereiro e março.

4.6. Ditassa glazioui E.Fourn. in Mart. \& Eichler, Fl. bras. 6(4): 250. 1885 (como "glaziovi”).

Trepadeira; ramos unilateralmente pubescentes, suberificados para a base. Pecíolo ca. $3 \mathrm{~mm}$ compr.; lâmina geralmente elíptica, ca. 1,3 cm compr., ca. $4 \mathrm{~mm}$ larg., cuneada na base, revoluta na margem, mucronada no ápice, glabra ou com tricomas esparsos na margem e na nervura central. Cimeiras geralmente 1-2-floras, subsésseis; pedicelo ca. 0,5 cm compr. Cálice esparsamente pubescente na base da face abaxial; sépalas lanceoladas, ca. 2,5 mm compr. Corola subcampanulada, creme-esverdeada, abaxialmente glabra, adaxialmente papilosa; tubo ca. 0,7 mm compr.; lacínias ca. 2,7 mm compr. Lobos da corona mais baixos que o ginostégio; segmentos triangulares, quase da mesma altura. Retináculo ligulado a rombóide, ca. 0,34 mm compr; caudículos retos, ca. 0,05 mm compr.; polínios obovóides, ca. $0,35 \mathrm{~mm}$ compr. (Fig. 3. A-C)

Silva et al. CFCR 12551 (RB, SPF).

Principalmente caatinga, na Bahia. Em Grão-Mogol, foi coletada com flor e fruto (n.v.) em dezembro, ocorrendo no cerrado, a cerca de $650 \mathrm{~m}$ s.m.

\subsection{Ditassa hispida.(Vell.) Fontella, Bradea 3(2): 5.1979.}

Trepadeira; ramos híspidos a pilosos. Pecíolo ca. 2 cm compr.; lâmina elíptica, ca. 3,2 cm compr., ca. 1,4 cm larg., arredondada na base, levemente revoluta na margem, aguda no ápice, híspida a pilosa em ambas as faces. Cimeiras subfasciculiformes, ca. 5-floras; pedúnculo ca. $1 \mathrm{~mm}$ compr.; pedicelo 5-7 mm compr. Cálice abaxialmente hirsuto; sépalas ovais, 1,5-1,55 $\mathrm{mm}$ compr. Corola subcampanulada, amarelada, abaxialmente glabra, adaxialmente puberulenta, glabrescente para o centro das lacínias; tubo 0,55-0,75 cm compr.; lacínias 3,6-3,65 mm compr. Segmentos da corona quase da altura do ginostégio; os externos sublineares; os internos lanceolados. Retináculo elipsóide, 0,21-0,23 mm compr.; caudículos retos, ca. 0,1 mm compr.; polínios subelipsóides, 0,21-0,23 mm compr. (Fig. 3. D-G)

Ferreira et al. $772(\mathrm{RB})$.

Rio Grande do Sul, Paraná, São Paulo, Rio de Janeiro, Minas Gerais e Bahia, mas sua distribuição pode abranger também outros países da América do Sul. Em Grão-Mogol, foi coletada com flores em maio.

4.8. Ditassa obcordata Mart., Nov. Gen. sp. pl. 1: 53. 1824.

Trepadeira; ramos pubescentes com regiões glabras. Pecíolo 1,5-3 mm compr.; lâmina elíptica, 0,8-1 cm compr., 4-5,5 mm larg., cuneada a arredondada na base, freqüentemente revoluta na margem, mucronada no ápice, glabra ou com tricomas esparsos na margem da base. Cimeiras umbeliformes, 1-3-floras; pedúnculo até $1 \mathrm{~mm}$ compr.; pedicelo 4-5 mm compr. Cálice glabro; sépalas ovais ou quase, ca. 0,9 mm compr. Corola rotácea, alva, abaxialmente glabra, adaxialmente puberulenta; tubo ca. 0,4 mm compr.; lacínias ca. 2,15 mm compr. Segmentos externos da corona triangulares, mais altos que o ginostégio; os internos digitiformes, mais baixos que o ginostégio. Retináculo elipsóide a subgloboso, ca. 0,15 mm compr.; caudículos retos, ca. 0,1 mm compr.; polínios suboblongos a oblanceolóides, ca. 0,25 mm compr. (Fig. 3. H-J)

\section{Hatschbach et al. 54210 (MBM).}

São Paulo, Minas Gerais, Espirito Santo, Bahia, Distrito Federal, Pará, Roraima e Rondônia. Floresce ao longo do ano; em Grão-Mogol, foi coletada com flores em junho.

4.9. Ditassa pohliana E.Fourn. in Mart. \& Eichler, Fl. bras. 6(4): 243. 1885 .

Trepadeira; ramos velutino-tomentosos. Pecíolo 2-6 mm compr.; lâmina oblonga a elíptica, $1-4 \mathrm{~cm}$ compr., 1-3(-5,5) mm larg., cuneada, truncada ou arredondada na base, levemente revoluta na margem, mucronada no ápice, adaxialmente velutina, pubescente ou pilosa, abaxialmente velutino-tomentosa. Cimeiras umbeliformes, freqüentemente bifurcadas na base, até 17-floras; pedúnculo até $3 \mathrm{~mm}$ compr.; pedicelo $2-5 \mathrm{~mm}$ compr. Cálice abaxialmente hirsuto; sépalas lanceoladas, ca. 1,4 $\mathrm{mm}$ compr. Corola rotácea, geralmente creme, abaxialmente hirsuta, adaxialmente puberulenta a glabra; tubo 0,25-0,4 mm compr.; lacínias ovais 1,4-1,95 mm compr. Segmentos externos da corona oblongos, mais baixos que o ginostégio; os internos suboblongos, inconspícuos. Retináculo elipsóide ou cônico, 0,15-1,75 mm 
compr.; caudículos retos, ca. $0,1 \mathrm{~mm}$ compr.; polínios obovóides a oblongos, 0,2-0,25 mm compr. (Fig. 3. KM)

Hatschbach 41399(MBM), 54159(HXBH, MBM, MO, UB); Pirani ${ }^{\circ}$ Mello-Silva CFCR 10890 (NY, RB, SPF).

Groiás, Minas Gerais e principalmente na Bahia, em campos rupestres e caatinga. Em Grão-Mogol, foi encontrada em carrasco, ca. $950 \mathrm{~m}$ s.m. Floresce de abril a julho.

\subsection{Ditassa retusa Mart., Nov. Gen. sp. pl. 1: 53. 1824.}

Trepadeira; ramos unilateralmente pubescentes, suberificados para a base. Pecíolo 2-5 mm compr.; lâmina oboval, 1,7-2,4 cm compr., 4-9(-14) mm larg., cuneada na base, levemente revoluta na margem, mucronada, arredondada a retusa no ápice, glabra ou com tricomas esparsos na margem. Cimeiras corimbosas, até 11-floras; pedúnculo 1-6 mm compr.; pedicelo 2-5 mm compr. Cálice glabro; sépalas orbiculares a oblongas, ca. $1 \mathrm{~mm}$ compr. Corola rotácea, alva ou creme, abaxialmente glabra, adaxialmente puberulenta; tubo ca. 0,5 mm compr.; lacínias ca. 2,5 mm compr. Lobos externos da corona subulados, ca. de 2,5 vezes mais altos que o ginostégio; os internos oblongos, quase da altura do ginostégio. Retináculo ligulado a elipsóide, ca. 0,2 $\mathrm{mm}$ compr.; caudículos retos, ca. 0,07 mm compr.; polínios ovóides a elipsóides, ca. $0,3 \mathrm{~mm}$ compr. Folículos ca. $5 \mathrm{~cm}$ compr., densamente alvo-tomentosos passando a verdes com a idade. (Fig. 3. N-P)

Bidá et al. CFCR 11959(HUEFS, RB, SPF); Cordeiro et al. CFCR 832 (RB, SPF); Furlan et al. CFCR 711 (RB, SPF); Hatschbach 41474 (MBM); Mamede et al. CFCR 3391 (RB,
SPF); Simão-Bianchini et al. CFCR 12821 (RB, SPF).

Campos, cerrados e carrasco, em Minas Gerais e na Bahia, mais raramente em São Paulo e Mato Grosso. Floresce ao longo do ano; em Grão-Mogol, foi coletada com flores em abril e maio e frutos em junho.

\subsection{Ditassa succedanea Rapini, nom. ined.}

Trepadeira; ramos uniformemente pubescentes, suberificado para a base. Pecíolo 2-5 mm compr.; lâmina oboval ou oblonga, 0,7-1,7 cm compr., 0,6-1,3 cm larg., arredondada a cuneada na base, levemente revoluta na margem, mucronada, retusa ou menos freqüentemente arredondada no ápice, glabra ou com tricomas esparsos adaxialmente na nervura central e na margem. Cimeiras umbeliformes, até 4-floras; pedúnculo ca. 0,3 $\mathrm{cm}$ compr.; pedicelo ca. 0,4 cm compr. Cálice com tricomas esparsos na face abaxial; sépalas ovais ou oblongas, ca. $2 \mathrm{~mm}$ compr. Corola subcampanulada, alva ou creme, abaxialmente glabra, adaxialmente puberulenta; tubo ca. 0,9 mm compr.; lacínias ca. 3,6 mm compr. Segmentos da corona mais altos que o ginostégio; os externos subobovais, sinuosos para o ápice, caudados; os internos subulados. Retináculo ligulado a elipsóide, ca. $0,25 \mathrm{~mm}$ compr.; caudículos retos a levemente arqueados, ca. 0,1 mm compr.; polínios obovóides a oblongos, ca. 0,5 mm compr. (Fig. 3. Q-T)

Cordeiro et al. CFCR 785 (RB, SPF); Semir et al. CFCR 9632 (RB, SPF).

Restrita a Minas Gerais, principalmente à Cadeia do Espinhaço, ocorrendo sobre plantas, entre rochas ou em solo arenoso. Floresce principalmente no primeiro semestre do ano.

\section{Hemipogon Decne.}

Ervas, subarbustos ou trepadeiras. Folhas opostas, verticiladas ou espiraladas, curtamente pecioladas a sésseis, lineares ou filiformes, glabras ou com tricomas esparsos na margem. Cimeiras umbeliformes, subaxilares, alternas. Cálice adaxialmente com até 2 coléteres entre as sépalas. Corola campanulada ou urceolada. Corona ausente, atrofiada ou mais raramente com lobos simples. Polínios pendentes. Ápice do ginostégio mamilado, incluso. Folículos fusiformes a falcados, glabros.

\subsection{Hemipogon carassensis (Malme) Rapini, comb. ined.}

Trepadeira; ramos glabros ou glabrescentes. Pecíolo 1-3 mm compr.; lâmina linear, 3-5 cm compr., 1-3 mm larg., atenuada na base, revoluta na margem, acuminada no ápice, tricomas esparsos na margem. Inflorescências umbeliformes, até 6-floras; pedúnculo $1-3 \mathrm{~cm}$ compr.; pedicelo 4-6 mm compr. Cálice glabro; sépalas trian- gulares, ca. $1 \mathrm{~mm}$ compr. Corola urceolada, amarela ou creme, abaxialmente glabra, adaxialmente barbada no ápice, serícea no terço médio, glabra na base; tubo ca. $3 \mathrm{~mm}$ compr.; lacínias ca. $1 \mathrm{~mm}$ compr. Retináculo elipsóide, ca. 2,5 mm compr.; caudículos geniculados, ca. 0,2 mm compr.; polínios piriformes a ovóides, ca. 0,4 mm compr. Folículos ca. $3 \mathrm{~cm}$ compr. (Fig. 3 . $\mathrm{U}-\mathrm{X})$ 


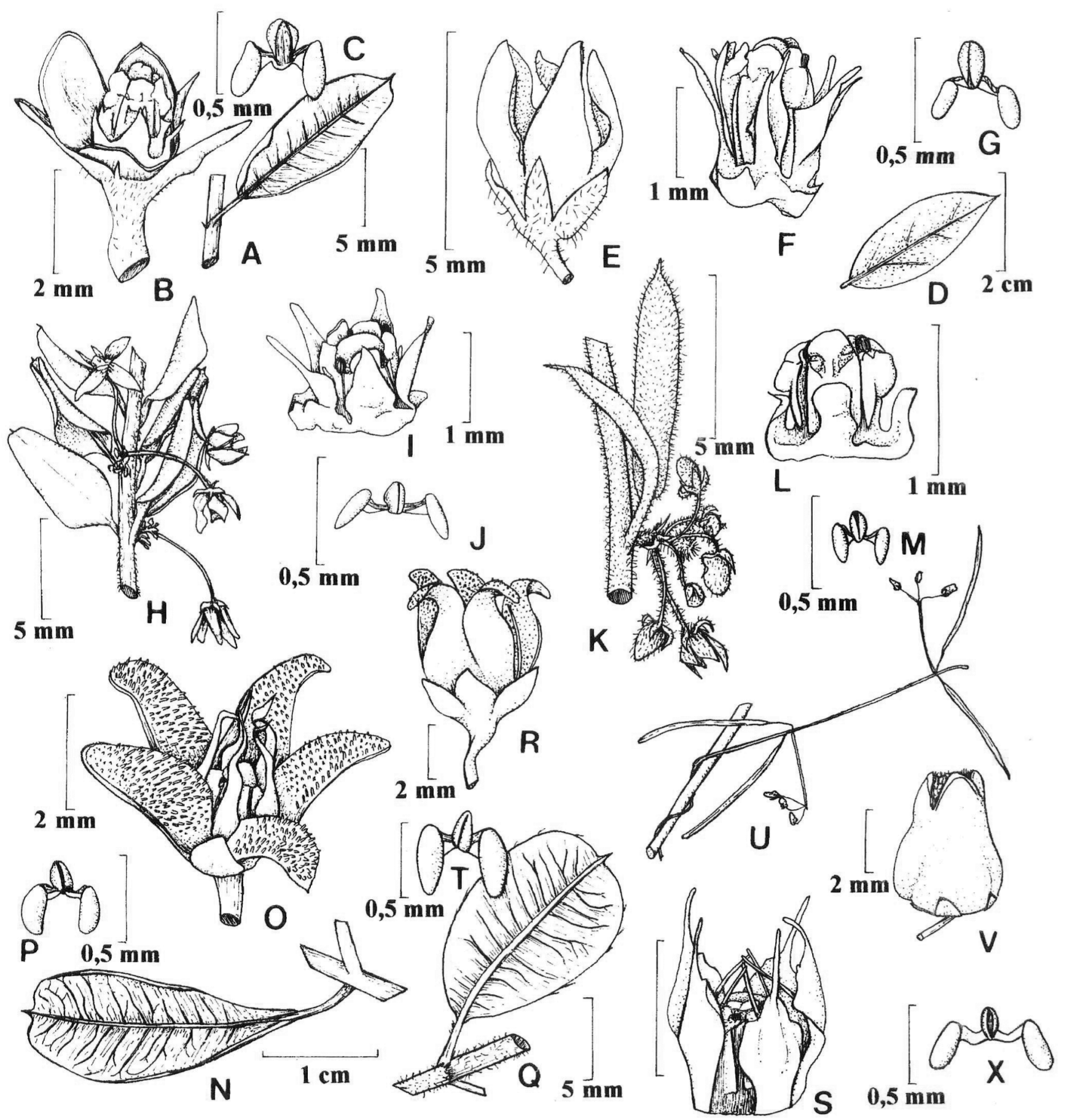

Fig. 3. APOCYNACEAE (ASCLEPIADOIDEAE). A-C. Dilassa glazioui: A. Folha; B. Flor com uma sépala e três lacínias retiradas; C. Polinário. D-G. D. hispida: D. Folha; E. Flor; F. Estames com corona; G. Polinário. H-J. D. obcordala: H. Parte do ramo com flores; I. Estames com corona; J. Polinário. K-M. D. pohliana: K. Par de folhas com inflorescência; L. Estames com corona; M. Polinário. N-P. D. relusa: N. Folha; O. Flor; P. Polinário. Q-T. D. succedanea: Q. Folha; R. Flor; S. Estames com corona; T. Polinário. U-X. Hemipogon carassensis: U. Parte do ramo com flores; V. Flor; X. Polinário (A-C. CFCR 1255; D-G. Ferreira 772; H-J. Hatschbach 54210; K-M. CFCR 10810; N-P. CFCR 711; Q-T. CFCR 785; U-X. CFCR 12854). 
Anderson et al. 8709.(MO); Cordeiro et al. CFCR 994 (RB, SPF); Irvin 23324 (MO); Lima 956 (RB); Simão-Bianchini et al. CFCR 12854 (RB, SPF).
Cerrados e campos rupestres de Minas Gerais, Bahia e, mais raramente, de São Paulo. Floresce principalmente em março e abril.

\section{Macroditassa Malme}

Trepadeiras; ramos glabros. Folhas opostas, pecioladas; lâmina geralmente elíptica ou quase. Cimeiras umbeliformes, axilares, até 3 por axila, opostas. Cálice glabro ou quase, adaxialmente com 1 coléter entre as sépalas. Corola campanulada a rotácea. Corona unida à corola e ao ginostégio; lobos duplos, livres entre si, opostos às anteras. Polínios pendentes. Ápice do ginostégio mamilado, incluso. Folículos fusiformes, prolongados, glabros.

6.1. Macroditassa adnata (Decne.) Malme, Ark. Bot. principalmente em maio e junho. 21A(3): 9.1927.

Trepadeira. Pecíolo 0,8-1,5 cm compr.; lâmina estreitamente oval a oblonga, 3-5,5 cm compr., 1,1-2,2 $\mathrm{cm}$ larg., arredondada na base, levemente revoluta na margem, mucronada no ápice, glabra. Cimeiras até 5floras; pedúnculo 0,5-2 cm compr.; pedicelo 3-6 mm compr. Sépalas ovais, ca. $1 \mathrm{~mm}$ compr. Corola subcampanulada a rotácea, creme ou esverdeada, abaxialmente glabra, adaxialmente puberulenta, barbelada na base; tubo 1-1,3 mm compr.; lacínias ca. 2,2-2,45 mm compr. Segmentos externos da corona oblongos a quase lanceolados, incurvados sobre o ginostégio; os internos subquadrangulares, seliformes, mais baixos que o ginostégio. Retináculo subgloboso, ca. $0,17 \mathrm{~mm}$ compr.; caudículos retos ou quase, ca. 0,05 mm compr.; polínios oblongos a obovóides, ca. 0,45 mm compr. (Fig. 4. A-D)

Hatschbach et al. 54220 (MBM); Prado et al. CFCR 12072 (BHCB, RB, SPF); Simão-Bianchini et al. CFCR 13008 (RB, SPF).

Paraná, São Paulo, Minas Gerais, Bahia, Goiás e Mato Grosso, na orla e no dossel de matas. Floresce

6.2. Macroditassa melantha (Silveira) Rapini, Bradea 8(32): 201.2001 (“2000”).

Trepadeira. Pecíolo ca. 2 mm compr.; lâmina oblonga a estreitamente elíptica, 1,6-2,2 cm compr., 0,7-1 cm larg., arredondada a cuneada na base, levemente revoluta na margem, mucronada no ápice, geralmente com tricomas na margem e na nervura central da face adaxial. Cimeiras umbeliformes, 4-10-floras; pedúnculo 1$4 \mathrm{~mm}$ compr.; pedicelo $4-5 \mathrm{~mm}$ compr. Sépalas ovais, ca. $0,65 \mathrm{~mm}$ compr. Corola rotácea, vinácea, abaxialmente glabra, adaxialmente incano-pubescente, setulosa na base; tubo ca. 0,5 mm compr.; lacínias ca. $1,35 \mathrm{~mm}$ compr. Segmentos da corona mais altos que o ginostégio; os externos oblongos, subulados; os internos lineares. Retináculo oblongo, 1,5-1,7 mm compr.; caudículos retos, ca. 0,05 mm compr.; polínios estreitamente ovais ou dacrióides, ca. 0,15 mm compr. (Fig. 4. E-G)

\section{Hatschbach et al. 52084 (MBM).}

Restrita à Cadeia do Espinhaço, em Minas Gerais e na Bahia. Em Grão-Mogol, foi coletada com flores em maio.

\section{Marsdenia R.Br.}

Trepadeiras, raramente subarbustos. Folhas opostas, raramente verticiladas, geralmente pecioladas, lanceoladas, ovais ou oblongas. Cimeiras axilares ou quase, alternas. Cálice adaxialmente com coléteres agrupados entre as sépalas ou ao longo da base. Corola subrotácea a urceolada. Lobos da corona unidos ao dorso das anteras, livres entre si, ou reduzidos. Polínios eretos. Ápice do ginostégio cônico ou obtuso.

7.1. Marsdenia suberosa (E.Fourn.) Malme, Bih. Kongl. Svenska Vetensk.-Akad. Handl. 34(7): 94. 1900.

Trepadeira; ramos unilateralmente pubescentes, suberificados para a base. Pecíolo 5-8 mm compr.; lâmina elíptica a oblonga, $6-9 \mathrm{~cm}$ compr., $1,5-4 \mathrm{~cm}$ larg., cuneada na base, plana na margem, mucronada, arre- dondada a retusa no ápice, glabra. Cimeiras axilares ou quase, condensadas no ápice, até 10-floras; pedúnculo 3-8 mm compr.; pedicelo $2-4 \mathrm{~mm}$ compr. Cálice glabro ou com tricomas na margem e na base da face abaxial; sépalas ovais a lanceoladas, 4-7 $\mathrm{mm}$ compr. Corola urceolada, amarelo-esverdeada, abaxialmente glabra, adaxialmente tomentosa na porção mediana; 
tubo ca. $7 \mathrm{~mm}$ compr.; lacínias ca. $6 \mathrm{~mm}$ compr. Lobos da corona sagitados, carnosos na base, internamente subulados, mais altos que o ginostégio. Retináculo estreitamente ovóide, ca. 0,5 mm compr.; caudículos retos, ca. 0,2 mm compr.; polínios cilíndricos, ca. 0,63 mm compr. (Fig. 4. H-K)
Silva et al. CFCR 12710 (RB, SPF), CFCR 12720 (BHCB, RB, SPF).

Rio de Janeiro, Minas Gerais e na Bahia. Floresce principalmente entre dezembro e março; em GrãoMogol, foi coletada com flores em dezembro.

\section{Oxypetalum R.Br.}

Trepadeiras, ervas ou subarbustos. Folhas opostas, geralmente pecioladas, ovais ou cordadas, freqüentemente subsésseis e lineares em plantas eretas. Cimeiras subaxilares, alternas. Cálice adaxialmente até 4 coléteres entre as sépalas. Corola geralmente com tubo curto, campanulado; lacínias geralmente lanceoladas a lineares, freqüentemente espiraladas e torcidas, eretas a reflexas. Corona unida à corola e ao ginostégio; lobos livres entre si, opostos às anteras. Polínios pendentes; caudículos geralmente dentados lateralmente. Ápice do ginostégio rostrado, prolongando-se em um apêndice bífido ou cilíndrico, excluso, raramente obtuso e incluso. Folículos fusiformes ou elipsóides, prolongados no ápice.

8.1. Oxypetalum erectum Mart., Nov. Gen. sp. pl. 1: 50. 1824.

Erva ca. $30 \mathrm{~cm}$ alt.; ramos vilosos. Folhas subsésseis; lâmina elíptica, ereta ou quase, 2,5-3 cm compr., 1,5-2 cm larg., arredondada na base, plana ou quase na margem, aguda no ápice, pilosa a pubescente em ambas as faces. Cimeira umbeliformes, subsésseis, 2-4-floras; pedicelo 5-7 mm compr. Cálice abaxialmente piloso; sépalas estreitamente oblongas, ca. $5,5 \mathrm{~mm}$ compr. Corola subcampanulada, abaxialmente pubescente, adaxialmente glabra ou quase; tubo ca. 2,5 mm compr.; lacínias ca. 1,2 cm compr. Lobos da corona escamiformes, corniculados adaxialmente. Retináculo laminar, suboblongo a espatulado, ca. $1 \mathrm{~mm}$ compr.; caudículos ca. 0,17 mm compr.; polínios reniformes, ca. 0,65 mm compr. Apêndice do ginostégio ca. 4,5 mm compr., bífido na metade apical. (Fig. 4. L-O)

\section{Markgraf 3343, Brade \& Barreto 12270 (BHMH).}

Vegetações abertas ou cangas de Santa Catarina, Paraná, São Paulo, Minas Gerais, Goiás, Distrito Federal e Mato Grosso, chegando até a Bolívia. Floresce entre setembro e maio, mais intensamente entre novembro e janeiro. O material de Grão-Mogol está com as flores destruídas e a descrição das estruturas reprodutivas está baseada em um material de Cristália, CFCR 8930 (SPF).
8.2. Oxypetalum strictum Mart., Nov. Gen. sp. pl. 1: 50. 1824.

Trepadeira ou arbusto volúvel; ramos hirsutos a vilosos. Pecíolo 5-7 mm compr.; lâmina oblonga a elíptica, obliquamente ereta a patente, 4-5 cm compr., 1,2-1,7 $\mathrm{cm}$ larg., truncada a subcordada na base, levemente revoluta na margem, mucronada no ápice, hirsuta a pilosa em ambas as faces. Cimeiras 1-2-floras; pedúnculo 3-5 mm compr.; pedicelo 3,5-5 mm compr. Cálice abaxialmente hirsuto; sépalas estreitamente triangulares, 4,5-5 mm compr. Corola subcampanulada a rotácea, creme ou esverdeada, abaxialmente hirtela, adaxialmente pubescente, eventualmente glabrescente para o ápice das lacínias; tubo 4,5-5 mm compr.; lacínias 1-1,15 cm compr. Lobos da corona bilobulados, cristados adaxialmente; lóbulos lunados ou quase. Retináculo conduplicado, oblongo a clavado, 1,8-1,9 mm compr.; caudículos ca. 0,25 mm compr.; polínios subsigmóides, 1,7-1,8 mm compr. Apêndice do ginostégio 6,5-9 mm compr., bífido na metade ou terço apical. (Fig. 4. P-T)

\section{Rapini E゚ Kawasaki 730, 753 (SPF).}

Cadeia do Espinhaço de Minas Gerais, mais raramente em São Paulo e na Bahia. Tipicamente ereta, encontra-se volúvel e com o indumento da face adaxial da corola menos denso em Grão-Mogol. Floresce ao longo do ano, mais intensamente em março. 


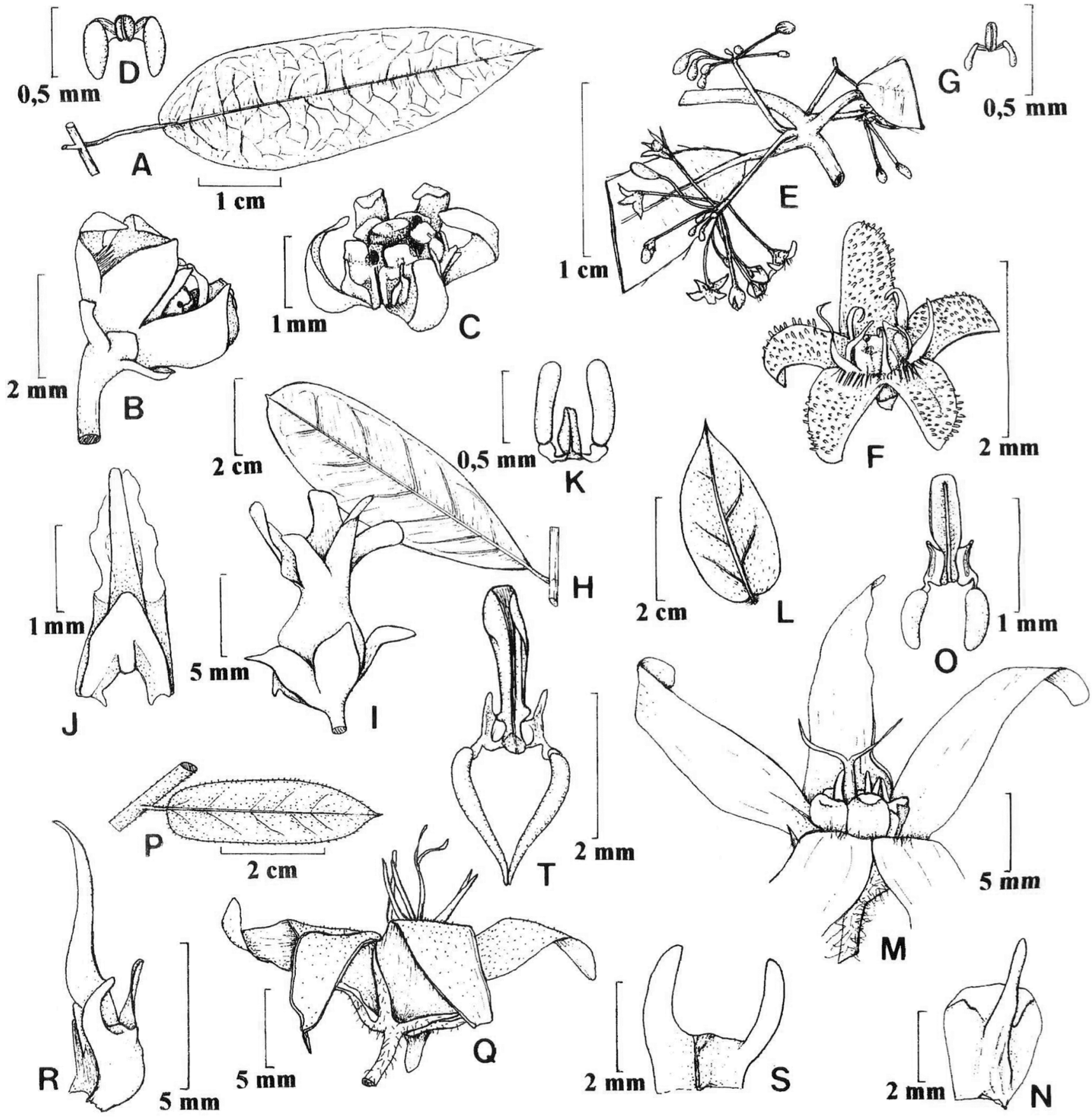

Fig. 4. APOCYNACEAE (ASCLEPIADOIDEAE). A-D. Macrodilassa adnata: A. Folha; B. Flor; C. Estames com corona; D. Polinário. E-G. M. melantha: E. Inflorescências; F. Flor; G. Polinário. H-K. Marsdenia suberosa: H. Folha; I. Flor; J. Antera com lobo da corona, vista abaxial; K. Polinário. L-O. Oxypetalum erectum: L. Folha; M. Flor com duas lacínias rebaixadas; N. Lobo da corona, vista adaxial; O. Polinário. P-T. O. strictum: P. Folha; Q. Flor; R. Estame com lobo da corona, vista lateral; S. Lobo da corona, vista adaxial; T. Polinário. (A-D. CFCR I2072; E-G. Hatschbach 52084; H-K. CFCR 12710); L-O. CFCR 893(); P-T. Rapini 753). 